\title{
Reinkluzja zęba 55 zaobserwowana w badaniu metodą tomografii stożkowej - opis przypadku
}

\author{
Reinclusion of tooth 55 observed in a cone beam computed tomography examination \\ - a case report
}

\author{
${ }_{1}^{1}$ Samodzielna Pracownia Propedeutyki Radiologii Stomatologicznej i Szczękowo-Twarzowej \\ Uniwersytet Medyczny w Lublinie \\ ${ }^{2}$ Klinika Chirurgii Szczękowo-Twarzowej, Uniwersytet Medyczny w Lublinie
}

DOI: http://dx.doi.org/10.20883/df.2017.15

\begin{abstract}
Streszczenie
Reinkluzja zęba (reinclusio dentis) to proces stopniowego oddalania się zęba całkowicie lub częściowo wyrżniętego od płaszczyzny zgryzu, a w przypadkach zaawansowanych- zatapiania się go w głąb kości wyrostka zębodołowego. O zębie zagłębionym mówi się w przypadku zwiększenia odległości jego powierzchni okluzyjnej, o co najmniej $1 \mathrm{~mm}$ od płaszczyzny zgryzu. Występowanie reinkluzji w polskiej populacji jest rzadkie, wynosi 0,07-1\%. Najczęściej zagłębianiu ulegają trzonowe zęby mleczne w żuchwie. Celem pracy było przedstawienie przypadku 6-letniej pacjentki skierowanej na badanie metodą tomografii stożkowej (ang. cone beam computed tomography, CBCT), które zostało wykonane aparatem KODAK 9000 3D, o polu obrazowania wys. $37 \mathrm{~mm}$, śr. 50 mm. Uwidoczniło ono reinkluzję drugiego prawego mlecznego zęba trzonowego w szczęce oraz trudny do zlokalizowania w badaniu dwuwymiarowym, znajdujący się podniebiennie zawiązek zęba 15. Kierując pacjentów na badania radiologiczne należy pamiętać o zasadzie ALARA (ang. as low as reasonably achievable). Oznacza to, że należy wykonać jak najbardziej przydatne diagnostycznie badanie, z jak najniższym narażeniem pacjenta na promieniowaniem rentgenowskie. Badanie CBCT, które może ograniczać się tylko do pożądanej okolicy, pozwala na dokładną ocenę sąsiednich struktur anatomicznych przy relatywnie niskiej dawce promieniowania.
\end{abstract}

Słowa kluczowe: ankyloza, tomografia stożkowa, uzębienie mleczne.

\begin{abstract}
Dental reinclusion is a process of the gradual distancing of a completely or partially erupted tooth from the occlusal plane, in advanced cases resulting in its immersion into the alveolar bone. Infraocclusion may be recognized in the case of an increased distance (at least $1 \mathrm{~mm}$ ) between the occlusal surface of a tooth and the occlusal plane of teeth. The prevalance of reinclusion in the Polish population is low, about $0.07-1 \%$. It frequently concerns milk molars in the mandible. The aim of the study was to present the case of a 6-year old patient referred for a cone beam computed tomography CBCT examination, which was taken with a KODAK 9000 3D device (field of view $37 \mathrm{~mm}$ vertical, $50 \mathrm{~mm}$ horizontal). It revealed reinclusion of the right maxillary primary second molar. The bud of tooth 15 was also observed, located palatally, which could be difficult to observe in two-dimensional radiological studies. Dentists who refer patients for radiological examinations should take into account the principle of ALARA (as low as reasonably achievable). This means that the most useful examination should be performed with the lowest possible dose of radiation. Volumetric tomography, which can be limited to the eligible area, allows for an accurate assessment of adjacent anatomical structures at a relatively low dose of radiation.
\end{abstract}

Keywords: tooth ankylosis, cone beam computed tomography, primary dentition.

\section{Wstęp}

Reinkluzja zęba (reinclusio dentis) to proces stopniowego oddalania się zęba całkowicie lub częściowo wyrżniętego od płaszczyzny zgryzu, a w przypadkach zaawansowanych zatapiania się go w głąb kości wyrostka zębodołowego. Stawia się to rozpoznanie już w przypadku zagłębienia się zęba o $1 \mathrm{~mm}$ [1-8]. Występowanie reinkluzji w polskiej populacji jest rzadkie, wynosi 0,07-1\%. [1] Częściej dotyczy zębów mlecznych niż stałych [7]. W badaniach Sobieskiej i wsp. [2] reinkluzja zębów mlecznych dotyczyła 4,2\% pacjentów w grupie 1003 osób.
Częściej dotknięte są tym schorzeniem zęby dolne [7], natomiast w szczęce proces zagłębiania zęba jest szybszy niż w żuchwie [4]. Wiek pacjenta ma wpływ na progresję reinkluzji - im później się pojawi, tym wolniej postępuje [5]. Resorpcja fizjologiczna korzeni reinkludowanego zęba mlecznego przebiega wolniej niż w przypadku zębów nieobjętych infraokluzją [9].

Nieprawidłowość ta często występuje rodzinnie, ponadto u tego samego pacjenta może wystąpić kilka zębów zagłębionych. Cozza i wsp. [4] opisali przypadek rodzeństwa, u którego wystąpiła 
reinkluzja. U 10-letniej pacjentki dotyczyła zębów: $55,65,84,85$, u jednego z 8,5-letnich bliźniąt zęba 55, a u drugiego 65.

Pod względem etiologii reinkluzja nie jest zaburzeniem jednorodnym [6]. Wśród przyczyn wymienia się: teorię inercji kostnej, uwarunkowania genetyczne, parafunkcje, dysfunkcje, przetrwały niemowlęcy typ połykania, przebyte urazy. Jednak najbardziej prawdopodobną bezpośrednią przyczyną reinkluzji wydaje się być ankyloza [1, 2, 4, 5].

Diagnostyka radiologiczna jest niezbędna w planowaniu postępowania z zębami zagłębionymi [4].

Celem pracy jest zaprezentowanie przypadku pacjentki, u której wykonanie badania tomografii wolumetrycznej pozwoliło na zaobserwowanie reinkludowanego mlecznego zęba trzonowego w szczęce po stronie prawej oraz jego stałego odpowiednika. Ząb 15 ułożony był podniebiennie, w taki sposób, że na zdjęciu dwuwymiarowym byłby trudny do dokładnego zlokalizowania.

\section{Opis przypadku}

Sześcioletnia pacjentka została skierowana na badanie CBCT, które wykonano aparatem Kodak 90003 o polu obrazowania (FOV) 37 mm wysokości, średnicy $50 \mathrm{~mm}$. Obrazowana objętość uwidoczniła zawiązki zębów stałych od 16 do 23, zęby mleczne w łuku od 54 do 62 oraz reinkludowany ząb 55 (Rycina 1). Korona prawego górnego drugiego mlecznego zęba trzonowego
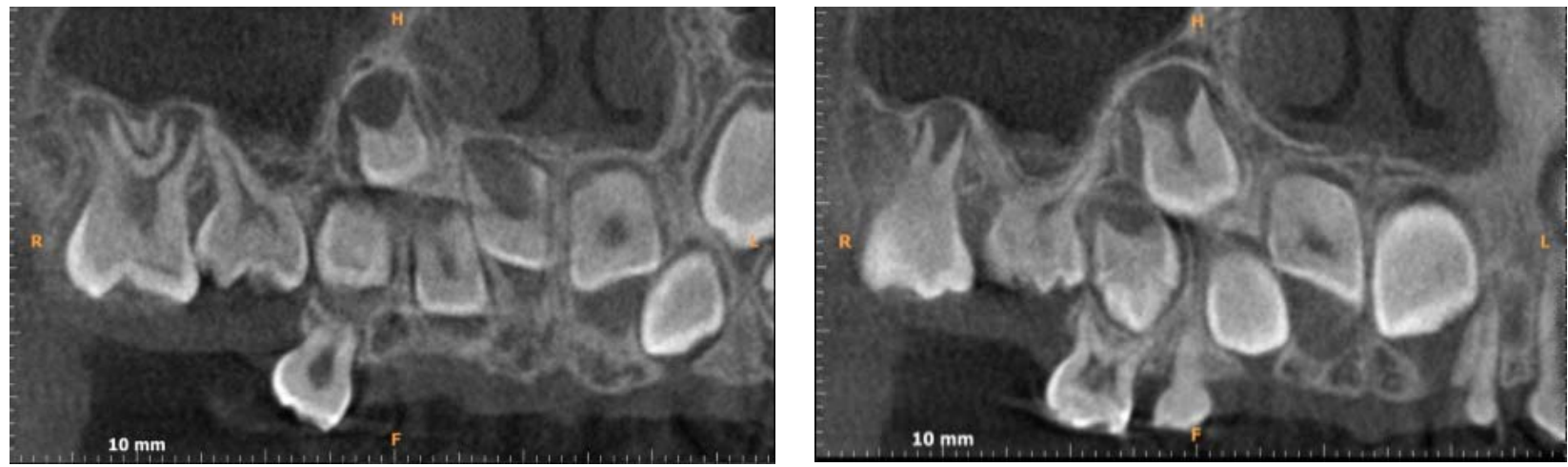

Rycina 1. Przekroje styczne. Widoczny reinkludowany ząb 55 bez cech resorpcji korzeni

Figure 1. Coronal CBCT scans. Reincluded tooth without visible features of physiological root resorption

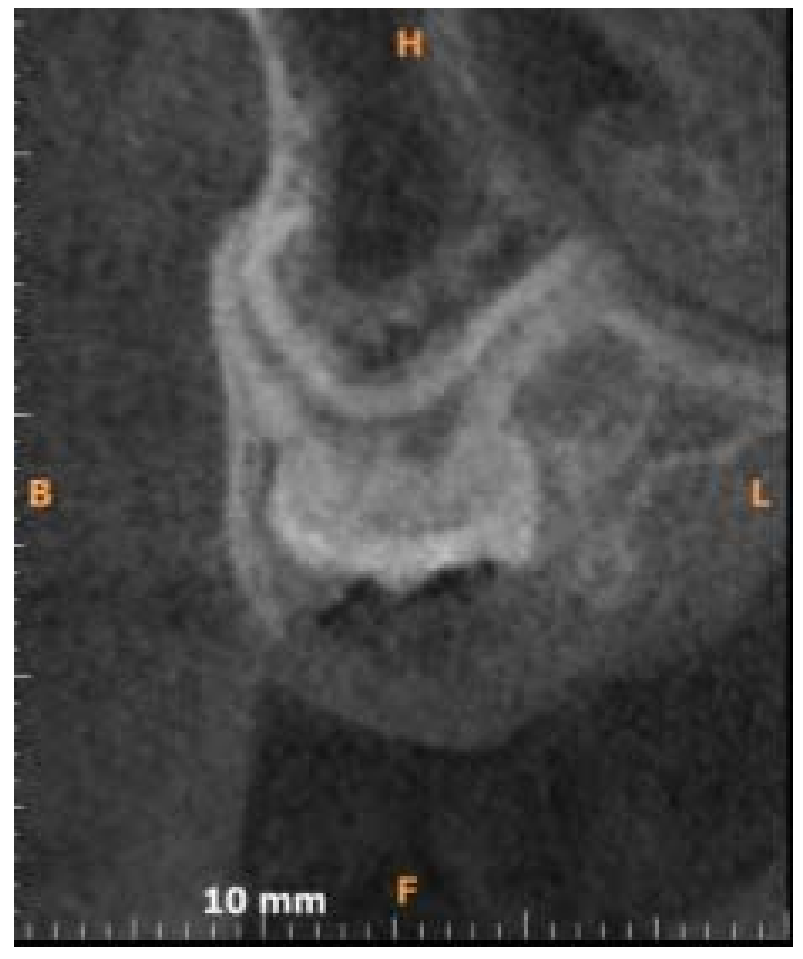

Rycina 2. Przekrój transsektalny zęba 55

Figure 2. Sagittal image of tooth 15

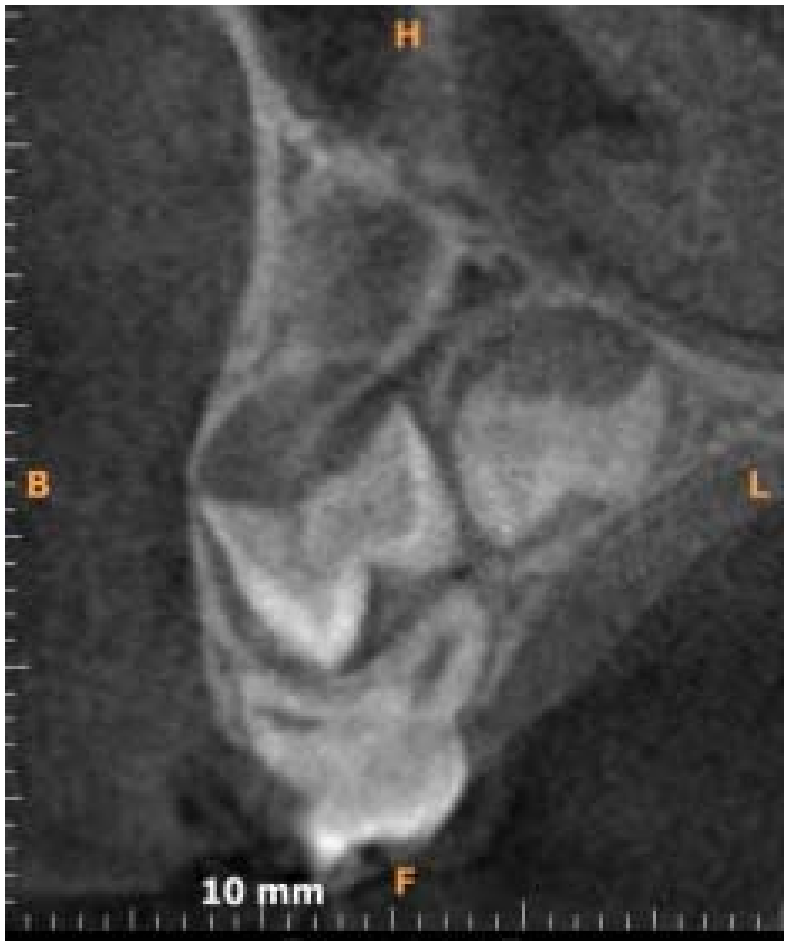

Rycina 3. Zawiązki zębów 15 i 14 są widoczne na przekroju transsektalnym

Figure 3. Germs of teeth 15, 14 are visible on sagittal CBCT scan 

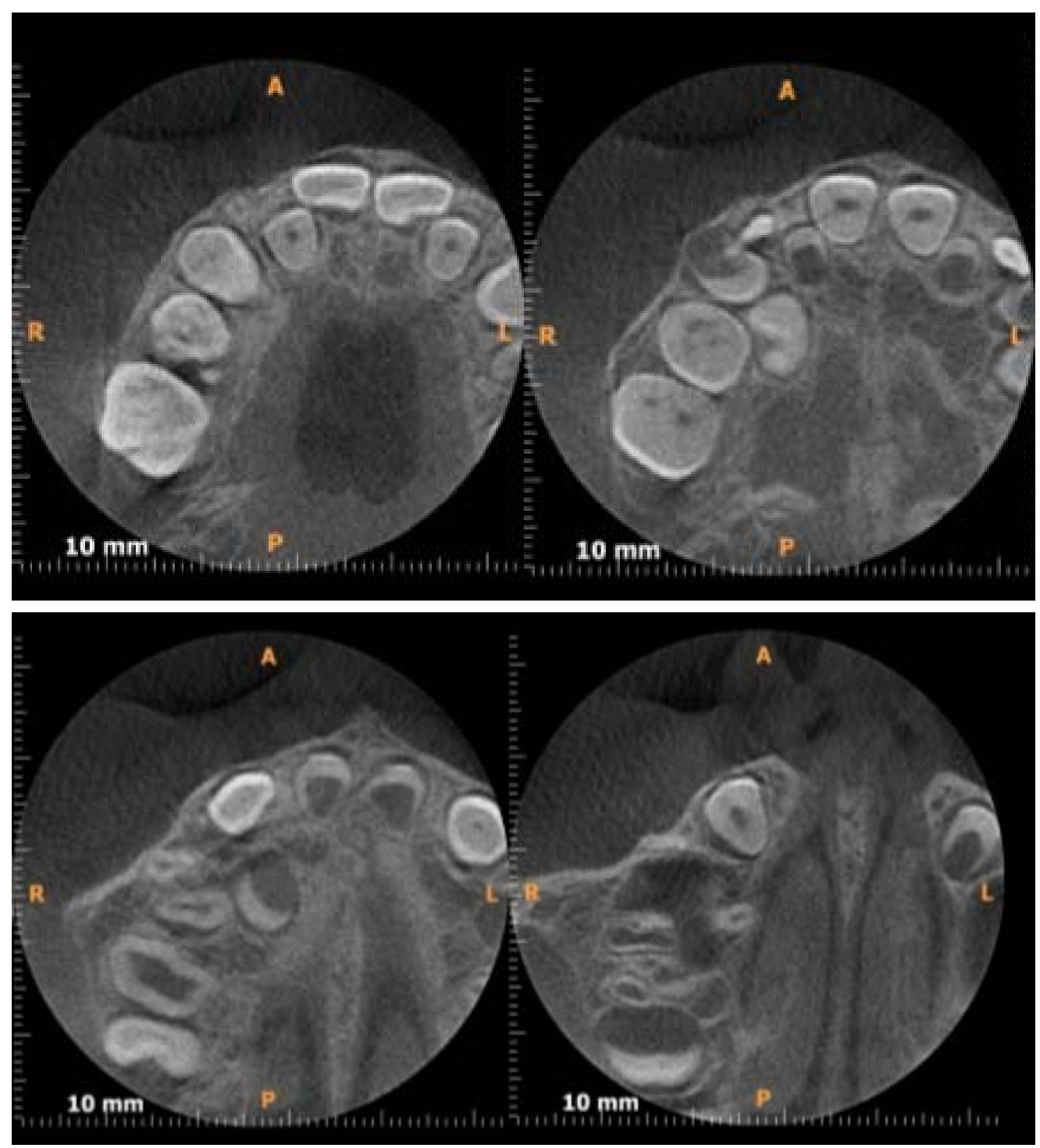

Rycina 4. Przekroje osiowe uwidaczniają ząb 55 i sąsiednie struktury. Zawiązek zęba 15 zlokalizowany podniebiennie

Figure 4. Axial images present tooth 55 and surrounding structures, the germ of tooth 15 located palatally

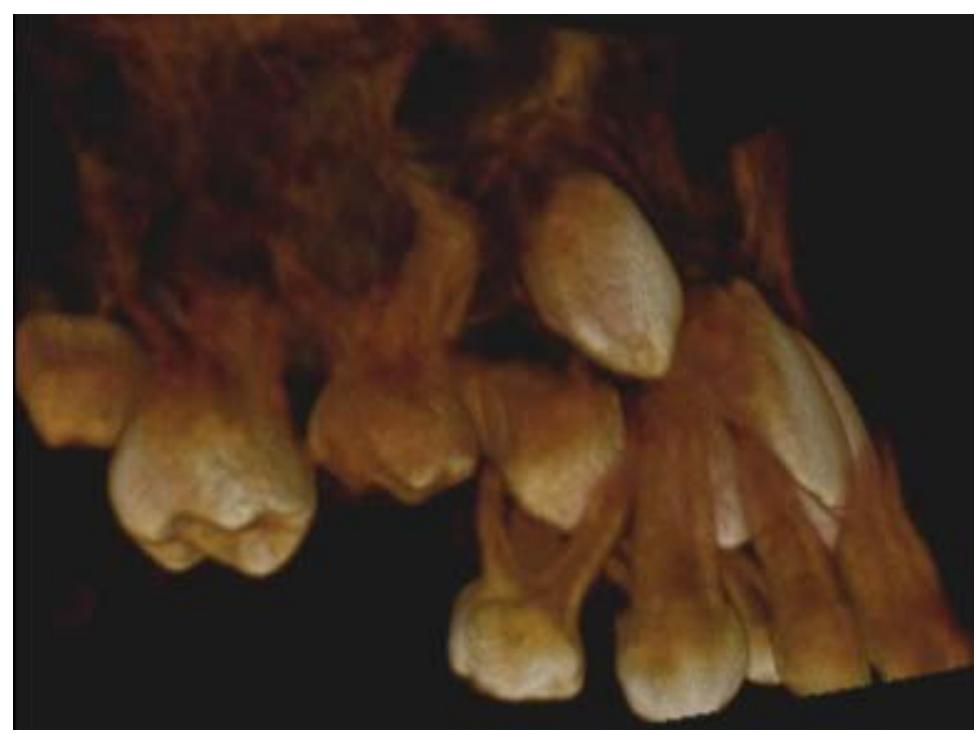

Rycina 5. Rzut pseudotrójwymiarowy zęba 55

Figure 5. 3-D reconstruction of tooth 55 
była wgłobiona w obręb wyrostka zębodołowego szczęki między zawiązkiem zęba 16 i zawiązkiem zęba przedtrzonowego, najpewniej 14 (Rycina 5). Korzenie zęba 55 nie wykazywały cech resorpcji. Korzeń policzkowy bliższy był spiralnie zagięty - w kształcie litery $\mathrm{C} w$ kierunku dystalnym na przekrojach stycznych oraz w kierunku podniebiennym na przekrojach transsektalnych (Rycina 3). Badanie ukazało wykształcone korony zębów 15 i 14. Zawiązek zęba 14 był obecny bezpośrednio nad zębem 54, a jego guzki policzkowe wchodziły do furkacji korzeniowej zęba 54. Oś zawiązka zęba 15 była skierowana skośnie - od dołu i strony podniebiennej ku górze i w stronę policzkową. Widoczna była niewielka resorpcja korzeni policzkowych zęba 54 od strony furkacji. Zawiązek zęba 15 był przemieszczony $\mathrm{i}$ ułożony podniebiennie $\mathrm{w}$ stosunku do zawiązka zęba 14 (Rycina 4).

Tak zaawansowane stadium reinkluzji wymagało ekstrakcji zęba mlecznego, którą przeprowadzono w Klinice Chirurgii Szczękowo-Twarzowej Uniwersytetu Medycznego w Lublinie.

\section{Omówienie}

Wykonanie badania tomografii stożkowej pozwoliło na ustalenie dokładnego położenia zagłębionego zęba 55 w stosunku do zębów stałych i mlecznych znajdujących się w sąsiedztwie. Analiza wyników pozwoliła na zlokalizowanie zęba 15 znajdującego się podniebiennie w stosunku do mlecznego odpowiednika. W tym przypadku wykonanie jedynie badania dwuwymiarowego mogło stwarzać podejrzenie wystąpienia hipodoncji zęba 15. Brak dokładnej diagnostyki stwarzałby ryzyko uszkodzenia podczas ekstrakcji obecnego w wyrostku zębodołowym szczęki drugiego górnego zęba przedtrzonowego.

Sposób postępowania zależy od wieku pacjenta, stopnia zagłębienia się zęba, zaawansowania resorpcji korzeni, położenia zęba stałego [4]. Wśród metod leczenia wyróżnia się: pozostawienie zęba i regularne monitorowanie kliniczne i radiologiczne, wczesne ekstrakcje z wykonaniem utrzymywacza przestrzeni, odbudowę korony. Parisay i wsp. [10] w swojej pracy zaproponowali, jako jedną z metod luksację zęba, która w opisanym przez nich przypadku wykonana dwa razy, spowodowała ponowne wyrznięcie się zęba.

Jeśli infraokluzja powoduje ryzyko zaburzenia prawidłowego wyrzynania zębów sąsiednich, powstanie wady zgryzu lub stanów zapalnych, ząb należy niezwłocznie usunąć $[5,9]$.

Metoda postępowania musi być zawsze dobrana indywidualnie do potrzeb pacjenta, co jest możliwe między innymi dzięki dokładnej diagnostyce radiologicznej, a w przypadkach zaawansowanych wykorzystaniu metody tomografii stożkowej [11].
Kierując pacjentów na badania radiologiczne należy wykonać jak najbardziej przydatne diagnostycznie badanie, z możliwie jak najniższym narażeniem pacjenta na promieniowaniem rentgenowskie. Badanie CBCT, które może ograniczać się tylko do pożądanej okolicy, pozwala na dokładną ocenę sąsiednich struktur anatomicznych przy relatywnie niskiej dawce promieniowania.

\section{Oświadczenia}

\section{Oświadczenie dotyczące konfliktu interesów}

Autorzy deklarują brak konfliktu interesów w autorstwie oraz publikacji pracy.

\section{Źródła finansowania}

Autorzy deklarują brak źródeł finansowania.

\section{Piśmiennictwo}

[1] Janiszewska-Olszowska J, Syryńska M, Sporniak-Tutak K. Reinkluzja stałych zębów trzonowych na podstawie piśmiennictwa i obserwacji własnych. Czas Stomatol. 2007; LX(12):797-805.

[2] Sobieska E, Sobczyńska M, Talik K, Zadurska M. Reinkluzja zębów mlecznych u pacjentów leczonych ortodontycznie. Forum Ortod. 2014;10:168-178.

[3] Bryan RAE, Welbury RR. Infraocclusion: a case report with an unexpected outcome. Europ J Paed Dent. 2002;2:97-100.

[4] Cozza P, Gatto R, Ballanti F, De Toffol L, Mucedero M. Case report: severe infraocclusion ankylosis occuring in siblings. Europ J Paediatr Dent. 2004;3:174-178.

[5] Mielnik-Błaszczak M, Skawińska A, Błaszczak J, Michałowski A. Reinkluzja zębów mlecznych. Mag Stomatol. 2017;1:26-28.

[6] Chalmers E, Goodall C, Gardner A. Coronectomy for infraoccluded lower first permanent molars:a report of two cases. J Orthod. 2012;39:117-121.

[7] Sidorowicz K, Sokalski J, Biedziak B, Pernak A. Reincluded Permanent Molar in the Mandible - Case Report. Dent Med Probl. 2006;43:621-623.

[8] Różyło TK, Różyło-Kalinowska I. Współczesna radiologia stomatologiczna. Lublin: Wyd. Czelej; 2012.

[9] Pectu A, Maxim A, Pasareanu M, Savin C. Relevance od primary molars in development of occlusion in mixed dentistion. Rom J Oral Rehabil. 2009;1:16-19.

[10] Parisay I, Kebriaei F, Varkesh B, Soruri M, Ghafourifard R. Management of a Severely Submerged Primary Molar: A Case Report. Case Rep Dent. 2013. doi.org/10.1155/2013/796242.

[11] Różyło-Kalinowska I. Bezpieczeństwo stomatologicznych badań radiologicznych w świetle zasad ochrony radiologicznej pacjenta i personelu. Forum Stomatol Prakt. 2016;5:38-42.

Zaakceptowano do edycji: 2017-04-12 Zaakceptowano do publikacji: 2017-04-22
Adres do korespondencji:
Lek. dent. Katarzyna Denkiewicz
Samodzielna Pracownia Propedeutyki Radiologii
Stomatologicznej i Szczękowo-Twarzowej
Uniwersytet Medyczny w Lublinie
ul. Karmelicka 7, 20-081 Lublin
tel.: +48 815287972
e-mail: denkiewicz.katarzyna@gmail.com 